\title{
Intraspecific Hybridization of Aspergillus awamori var. kawachi by Protoplast Fusion
}

\author{
Kihachiro Ogawa, Hitoshi OHara and Nobuo Toyama \\ Applied Microbiology Laboratory, Department of Agricultural Chemistry, \\ Faculty of Agriculture, Miyazaki University, \\ Miyazaki 889-21, Japan \\ Received July 31, 1987
}

\begin{abstract}
Protoplast fusion was studied to breed a koji-mold, Aspergillus awamori var. kawachi, used for making a Japanese spirit, shochu. Protoplasts were obtained from mycelia of two biochemical mutants using an enzyme system from Trichoderma viride consisting of mainly $\beta$-1,3-glucanase and chitinase. Approximately $10 \sim 20 \%$ of these protoplasts regenerated on a solid culture medium with a soft agar overlay. When the two types of protoplasts were treated with a fusogen including $35 \%$ polyethylene glycol, they fused effectively and formed a heterokaryon. A strain obtained from the hetrokaryon using $d$-camphor showed high stability $(98.8 \%)$ and numerical sporulation, and produced the same levels of amylase and citric acid as those by the original strain. From these results and the formation of recombinants, the new strain was assumed to be a heterozygous diploid. The appearance frequency of the diploid was $2.9 \times 10^{-2}$. The existence of a parasexual cycle in this fungus was also discovered, using the protoplast fusion technique.
\end{abstract}

Shochu is a traditional alcoholic drink in Japan. Aspergillus awamori var. kawachi, Aspergillus kawachii Kitahara (a mutant of $A$. awamori var. kawachi) and Aspergillus oryzae have been commonly used for making shochu, but there have not reports of studies on genetic and active breeding of koji-molds used for making shochu.

In recent years, fungal breeding using protoplast fusion techniques has been performed throughout the world. Many studies concerned the intra- and inter-specific protoplast fusion of filamentous fungi, including strains of Aspergillus, ${ }^{144)}$ Penicillium, ${ }^{5)}$ Mucor ${ }^{6)}$ and Trichoderma. ${ }^{7,8)}$ Although heterokaryon formation through protoplast fusion seems to be an effective method for analyzing a parasexual cycle, no studies concerning koji-molds used for making shochu have been reported as yet.

The present study was undertaken to determine the feasibility of koji-mold breeding through protoplast fusion and to obtain a useful strain for making shochu. We attempted to clarify the conditions for the intraspecific fusion and regeneration of $A$. awamori var. kawachi and to establish a method for obtaining heterokaryons from among different biochemical mutants derived from the fungus. The heterozygous diploid derived from the heterokaryons obtained was shown to be stable and useful as an original strain.

\section{MATERIALS AND METHODS}

Organisms. The citric acid hyper producer, A. awamori var. kawachi KGS (Kawachi Genichiro Shoten), used for making shochu, was employed as the original strain. Conidia of this strain were treated with UV rays in a routine manner. The auxotrophic single mutants obtained were checked as to their stability over several vegetative generation, and as to their characteristic citic acid and amylase production. Strain KGS-1 (met) and KGS-2 (arg) are mutants of $A$. awamori var. kawachi KGS, respectively. These parental strains also produced single nucleus conidia on a complete medium.

Mycolytic enzyme sources. Commercial enzyme preparations, Zymolyase 5,000 (Seikagaku Kogyo Co., Ltd.) and Halicase (Reactif de Laboratorie), and a Trichoderma viride BIA preparation" were used in this work.

Cultivation of microorganisms. Czapek Dox medium 
containing $2 \%$ glucose was used as a minimal medium (MM). The minimal medium supplemented with $0.5 \%$ yeast extract and casamino acid was used as a complete medium (CM).

Enzyme assays. $\quad \beta-1,3-G l u c a n a s e$ activity: A reaction mixture consisting of $0.5 \mathrm{ml}$ of a $1 \%$ laminarin (Tokyo Chem. Ind. Co., Ltd.) solution ( $0.1 \mathrm{M}$ acetate buffer, $\mathrm{pH}$ 5.0 ) and $0.5 \mathrm{ml}$ of an adequately diluted enzyme soution was incubated at $45^{\circ} \mathrm{C}$ for $30 \mathrm{~min}$. The reducing sugar was determined by the 3,5-dinitrosalicylic acid method. ${ }^{10)}$ One unit of $\beta$-1,3-glucanase activity was defined as the amount of enzyme which produced $1 \mu \mathrm{mol}$ of reducing sugar as glucose per min. Chitinase activity: in a test tube, $1 \mathrm{ml}$ of a $1 \%$ colloidal chitin suspension (prepared from chitin, shrimp; Wako Pure Chem. Ind. Ltd.) and $1 \mathrm{ml}$ of an appropriately diluted enzyme solution were incubated in a water bath at $\mathrm{pH} 5.0$ and $40^{\circ} \mathrm{C}$ for $60 \mathrm{~min}$. The amount of NAG ( $N$-acetyl-D-glucosamine) was determined by the modified method of Reissig. ${ }^{11}$ One unit of chitinase activity was defined as the amount of enzyme which liberated $1 \mu \mathrm{mol}$ of NAG.

Amylase activity: This activity was assayed according to our $\beta$-1,3-glucanase activity assay method using a $2 \%$ soluble starch (Wako Pure Chem. Ind.) solution. The enzyme unit was also defined in the same manner as before.

Preparation of protoplasts. A loopful of a conidiamycelial mixture was taken from a slope, added to $50 \mathrm{ml}$ of the liquid complete medium in a $100 \mathrm{ml}$ Erlenmeyer flask, and then incubated at $30^{\circ} \mathrm{C}$ and $18 \mathrm{hr}$ on a rotary shaker $(150 \mathrm{rpm})$. After incubation, the mycelia were collected on filter paper (Toyo No. 2) and then washed with distilled water under aseptic conditions. About $200 \mathrm{mg}$ (wet weight) of mycelia was then added to $5 \mathrm{ml}$ of a $3 \%(\mathrm{w} / \mathrm{v}) T$. viride BIA mycolytic enzyme solution, made to $0.6 \mathrm{M}$ with respect to $\mathrm{NaCl}$ (or $\mathrm{NH}_{4} \mathrm{Cl}$ ), followed by incubation in a Monod shaking apparatus at $\mathrm{pH} 5.0$ and $35^{\circ} \mathrm{C}$ for 1 to $2 \mathrm{hr}$. The reaction mixture was filtered through $\mathrm{G} 2$ and $\mathrm{G} 3$ porosity sintered glass filter, and the filtrate was centrifuged at $700 \times g$ for $5 \mathrm{~min}$. The sedimented protoplasts were suspended in a $1 \mathrm{ml}$ solution $(0.6 \mathrm{M} \mathrm{NaCl})$, which was osmotically balanced.

Protoplast fusion. Fusion was carried out according to a modification of the method of Anne and et al. ${ }^{12)}$ Protoplasts were prepared from both biochemical mutants. Protoplasts of each mutant were mixed and then centrifuged at $700 \times g$ for $5 \mathrm{~min}$. This procedure was repeated several times to purify the protoplasts. The sedimented protoplasts were resuspended in $1 \mathrm{ml}$ of a solution of $35 \%(\mathrm{w} / \mathrm{v})$ polyethylene glycol 4,000 (PEG; av. mol. wt., 3,000; Wako Pure Chem. Ind. Ltd.) and $0.05 \mathrm{M}$ $\mathrm{CaCl}_{2} \cdot 2 \mathrm{H}_{2} \mathrm{O}$ in $0.05 \mathrm{M}$ glycine- $\mathrm{NaOH}$ buffer ( $\mathrm{pH} 7.5$ ). After standing at $20^{\circ} \mathrm{C}$ for $15 \mathrm{~min}$, the suspension was centrifuged at $700 \times g$ for $5 \mathrm{~min}$. The sedimented protoplasts were resuspended in $1 \mathrm{ml}$ of an osmotically balanced medium and then plated onto hypertonic MM and $\mathrm{CM}$ containing $2 \%$ agar and $0.6 \mathrm{M} \mathrm{NaCl}$ in Petri dishes, and then overlayed with the same $\mathrm{MM}$ containing $0.5 \%$ agar. After incubation at $25^{\circ} \mathrm{C}$ for 4 days, the colonies showing successful fusion were counted and the fusion frequency was estimated.' The fusion frequency was defined as the percentage ratio of the numbers of colonies developing on MM and CM after the fusion treatment.

Diploidization of heterokaryons. A solution of $0.1 \mathrm{~g}$ of $d$ camphor dissolved in $1 \mathrm{ml}$ of $99 \%$ ethanol was added to $99 \mathrm{ml}$ of a MM solution containing $2 \mathrm{~g}$ of powdered agar. This mixture was autoclaved at $120^{\circ} \mathrm{C}$ for $15 \mathrm{~min}$. The autoclaved MM agar solution was poured into a Petri dish and allowed to solidify. Heterokaryon strain KGS-1-2-H was inoculated onto the $\mathrm{MM}$ agar and kept at $25^{\circ} \mathrm{C}$ for 7 days.

Solid culture for enzyme preparation. Twenty grams of rice grains moistened with tap water in a $300 \mathrm{ml}$ Erlenmeyer flask was autoclaved at $25^{\circ} \mathrm{C}$ for $20 \mathrm{~min}$. The flask was inoculated with a loopful of mycelia and then incubated at $25^{\circ} \mathrm{C}$ for 5 days. Enzyme activity was assayed in the filtrate prepared by extracting the solid culture with 10 volumes of distilled water for $1 \mathrm{hr}$.

Determination of DNA. Determination of DNA was carried out according to the method of Burton ${ }^{13)}$ after extraction by the method of Schneider. ${ }^{14)}$ The DNA content per conidium was calculated as follows: $100 \times$ (the amount of DNA in the conidia)/(the number of conidia tested) $\left(10^{-6} \mu \mathrm{g}\right)$.

\section{RESULTS}

\section{Protoplast formation and regeneration}

The mycolytic enzyme activities of $T$. viride B1A and commercial enzyme preparations were assayed (Table I). Mycelial pellets of $A$. awamori var. kawachi prepared from rotary shaken cultures were used in this study. Numerous protoplasts appeared within 1 to $2 \mathrm{hr}$ from mycelia degraded with the $T$. viride enzyme preparation. Although the enzyme from $T$. viride gave the highest yield of protoplasts, the other enzyme preparations did not act effectively in case of $A$. awamori var. kawachi. The protoplasts purified by washing were plated on CM agar. In the early stage, the protoplasts swelled somewhat, and later showed two types of regeneration: the for- 
mation of chains of yeast-like cells and the direct formation of hyphae. ${ }^{15)}$

\section{Heterokaryon formation}

Protoplasts from the biochemical mutants, KGS-1 and KGS-2 were fused as described under Materials and Methods. Protoplast fusion usually occurred between two cells or among three cells. The regeneration ratio for the protoplasts was defined as the percentage ratio of the number of colonies appearing on the osmotically balanced CM and the total number of protoplasts of the original mutant. The regeneration ratios of the biochemical mutants used in this test was 10 to $20 \%$, respectively. The fusion frequency was $9 \times 10^{-3}$ (Table II). After 4 days incubation, 10 to 25 colonies developed on the MM agar in the Petri dish.

\section{Properties of the fusants}

The colonies of fusants that appeared on the

Table I. Mycolytic Enzyme Activities of THE ENZYME PREPARATIONS

\begin{tabular}{lcc}
\hline Preparation & $\begin{array}{c}\beta-1,3-\text { Glucanase } \\
\text { (units/ml) }\end{array}$ & $\begin{array}{c}\text { Chitinase } \\
\text { (units/ml) }\end{array}$ \\
\hline $\begin{array}{l}\text { T. viride lytic enzyme } \\
\text { preparation }\end{array}$ & 17.20 & 0.392 \\
$\begin{array}{l}\text { Zymolyase-5000 } \\
\text { Helicase }\end{array}$ & 0.69 & 0.006 \\
& 1.80 & 0.096 \\
\hline
\end{tabular}

a This preparation was prepared by the tannic acid polyethylne glycol method developed in our laboratory.
MM agar were transferred to MM agar slants, respectively. Most of the colonies showed fine growth on the slants. Most fusants also segregated exactly into two types of parental auxotrophs, and produced sectors. These results evidently showed that the fusants were heterokaryons.

\section{Formation of heterozygous diploids}

It has been shown that the frequency of diploidization from heterokaryons can be enhanced by treatment with $d$-camphor. ${ }^{16)} \mathrm{A}$ loopful of heterokaryon mycelia from the slant was incubated on MM agar containing $0.1 \%$ $d$-camphor, followed by further incubation at $25^{\circ} \mathrm{C}$ for 7 days. After incubation, some sectors were also seen for the colonies grown on MM agar. It was suggested that these sectors were due to the formation of diploids in the colonies. When appropriately diluted conidia in a sector were plated on fresh MM agar, the conidia were almost able to germinate on the MM agar, as evident in Fig. 1. If these conidia are heterokaryotic, they ought to segregate into both types of parental auxotrophic conidia on the MM agar. These conidia could not consequently grow on the MM agar. Therefore, the resulting strains that could grow on the MM agar were regarded as heterozygous diploids. The frequency of diploidization was $2.9 \times 10^{-2}$ (Table III). As shown in Fig. 2, it was suggested that a diploid strain KGS-1-2-D, grew more vigorously than a heterokaryotic strain, KGS-1-2-H,

Table II. Fusion Frequency between Protoplasts of Auxotrophic Mutants

\begin{tabular}{|c|c|c|c|c|}
\hline \multirow{2}{*}{$\begin{array}{l}\text { Protoplast } \\
\text { pair }\end{array}$} & \multicolumn{2}{|c|}{$\begin{array}{c}\text { Protoplasts regenerated } \\
\text { on hypertonic CM }\end{array}$} & \multirow{2}{*}{$\begin{array}{c}\text { Fusant formed on } \\
\text { hypertonic MM }\end{array}$} & \multirow{2}{*}{ Fusion frequency } \\
\hline & $\begin{array}{l}\text { Before fusion } \\
\text { treatment }\end{array}$ & $\begin{array}{l}\text { After fusion } \\
\text { treatment }\end{array}$ & & \\
\hline KGS-1 (met) & $2.51 \times 10^{6}$ & $2.65 \times 10^{5}$ & & \\
\hline $\begin{array}{l}+ \\
\mathrm{KGS}-2(\arg )\end{array}$ & $2.50 \times 10^{6}$ & $2.90 \times 10^{5}$ & $5.0 \times 10^{3}$ & $9 \times 10^{-3}$ \\
\hline
\end{tabular}

Czapek-Dox medium containing $2 \%$ glucose was used as the minimal medium (MM). MM supplemented with $0.5 \%$ yeast extract and casamino acid was used as the complete medium (CM). Fusion was accomplished by suspending the protoplasts in $35 \%$ PEG 4,000, $0.05 \mathrm{M} \mathrm{CaCl}_{2}, 0.05 \mathrm{M}$ glycine- $\mathrm{NaOH}$ buffer, $\mathrm{pH} 7.5\left(25^{\circ} \mathrm{C}\right.$ for $\left.15 \mathrm{~min}\right)$. After washing with $0.6 \mathrm{M} \mathrm{NaCl}$, a series of appropriately diluted protoplast suspensions were plated onto hypertonic $\mathrm{MM}$ and $\mathrm{CM}$ agar. 
Table 1II. Segregation of Heterokaryons after Fusion and the Appearance Frequency OF DIPLOIDS

\begin{tabular}{cccc}
$\begin{array}{c}\text { Protoplast } \\
\text { pair }\end{array}$ & $\begin{array}{c}\text { Reversion rate } \\
\text { (less than) }\end{array}$ & $\begin{array}{c}\text { Segregation into } \\
\text { auxotrophs }(\%)\end{array}$ & $\begin{array}{c}\text { Appearance frequency } \\
\text { of diploids }\end{array}$ \\
\hline $\begin{array}{c}\text { KGS-1 (met) } \\
+\end{array}$ & $2.1 \times 10^{-6}$ & 70 & $2.9 \times 10^{-2}$ \\
KGS-2 (arg) & $3.5 \times 10^{-6}$ & 30 & \\
\hline
\end{tabular}

The reversion rate was defined as the ratio of the numbers of protoplasts regenerating on $\mathrm{CM}$ and $\mathrm{MM}$ agar.

Appearance frequency of diploids was defined as the ratio of the numbers of conidia regenerating on $\mathrm{CM}$ and $\mathrm{MM}$ agar.

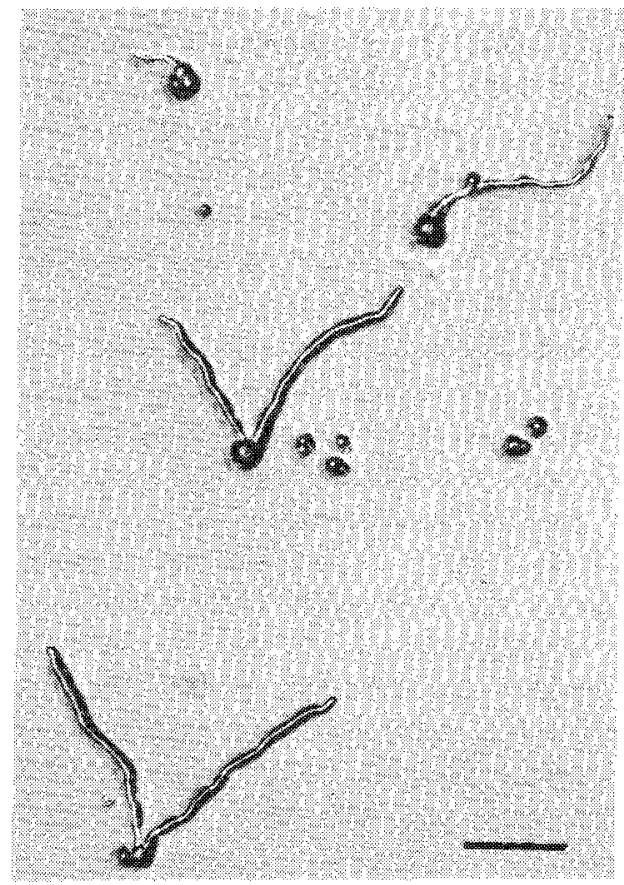

Fig. 1. Germination of Diploid Conidia on Minimal Medium.

The photomicrograph was taken after $18 \mathrm{hr}$ incubation at $25^{\circ} \mathrm{C}(\times 150)$. The bar marker represents $30 \mu \mathrm{m}$.

on the MM agar. The strain showed an about 1.4 fold DNA content per conidium (Fig. 3 and Table IV). Moreover, the conidial diameters of the diploids were about two fold those of the parental or original strains. Although $98.8 \%$ of the total conidia were stable, some recombinants were spontaneously produced from the conidia (Table $\mathrm{V})$. In the solid rice grain culture of the diploid strain, KGS-1-2-D, the citric acid and amylase productivities were the same as those

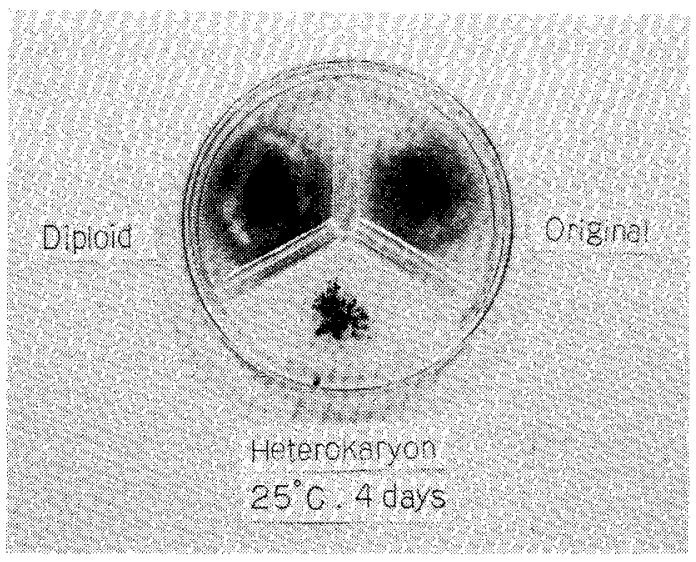

FIG. 2. Difference in Growth between the Heterokaryon and Diploid on Minimal Medium.

The photomicrograph was taken after 4 days incubation on $25^{\circ} \mathrm{C}$.

Table IV. Size and DNA Content of Conidia of THE Haploid AND DiploId

\begin{tabular}{lcc} 
Strain & $\begin{array}{c}\text { Size (dia.) } \\
(\mu \mathrm{m})\end{array}$ & $\begin{array}{c}\text { DNA content } \\
\left(10^{-6} \mu \mathrm{g} \text { per }\right. \\
\text { conidium) }\end{array}$ \\
\hline $\begin{array}{l}\text { Strain KGS } \\
\text { (haploid) }\end{array}$ & $\begin{array}{c}2.5 \sim 4.5 \\
\text { (Ave. } 4.0)\end{array}$ & 10.69 \\
$\begin{array}{l}\text { Strain KGS-1-2-D } \\
\text { (diploid) }\end{array}$ & $\begin{array}{c}5.0 \sim 7.5 \\
(\text { Ave. 5.2) }\end{array}$ & 21.17 \\
\hline
\end{tabular}

a The conidial sizes of the original strain and the biochemical mutants, KGS-1 (met) and KGS-1 ( $\mathrm{arg}$ ), were much smaller than that of the diploid, respectively. In this table, the conidial size of the original strain is shown.

of the original strain, KGS. Those of KGS-1, KGS-2 and KGS-1-2-H, however, were very low (Table VI). Moreover, strains KGS-1, KGS-2 and KGS-1-2-H showed poor growth 
and poor conidiation on the rice grain culture. On the other hand, strain KGS-1-2-D grew well on the rice grain culture and showed

Table V. Segregation of Biochemical Mutants FROM THE DIPLOID

\begin{tabular}{|c|c|c|c|c|}
\hline \multirow{2}{*}{ Prototroph } & & \multicolumn{2}{|c|}{$\begin{array}{c}\text { Auxotrophic } \\
\text { mutant }\end{array}$} & \multirow{2}{*}{ Total } \\
\hline & & met & $\arg$ & \\
\hline 2191 & & 3 & 1 & 2195 \\
\hline Black conidia & 2174 & & & \\
\hline $\begin{array}{l}\text { No conidia and color } \\
\text { changed conidia }\end{array}$ & 17 & & & \\
\hline
\end{tabular}

A conidial suspension of the diploid strain, KGS-1-2-D, was plated on CM agar and then incubated at $25^{\circ} \mathrm{C}$ for 4 days. The colonies appearing were transferred onto $\mathrm{MM}$ agar. The colonies that did not grow were further tested as to their nutritional requirements. healthy sporulation on it.

\section{DISCUSSION}

A useful strain for making shochu needs to exhibit high citric acid and amylase productivities. Protoplast fusion techniques have not yet been applied to the field of shochu kojimold breeding for making shochu. We obtained new diploid strains through protoplast fusion, and for the first time, found the presence of a parasexual cycle in A. awamori var. kawachi.

The protoplast fusants obtained in this study were able to grow on MM agar, and conidia from the fusants completely segregated into two types of parental auxotrophs. These results showed that the protoplast fusants were

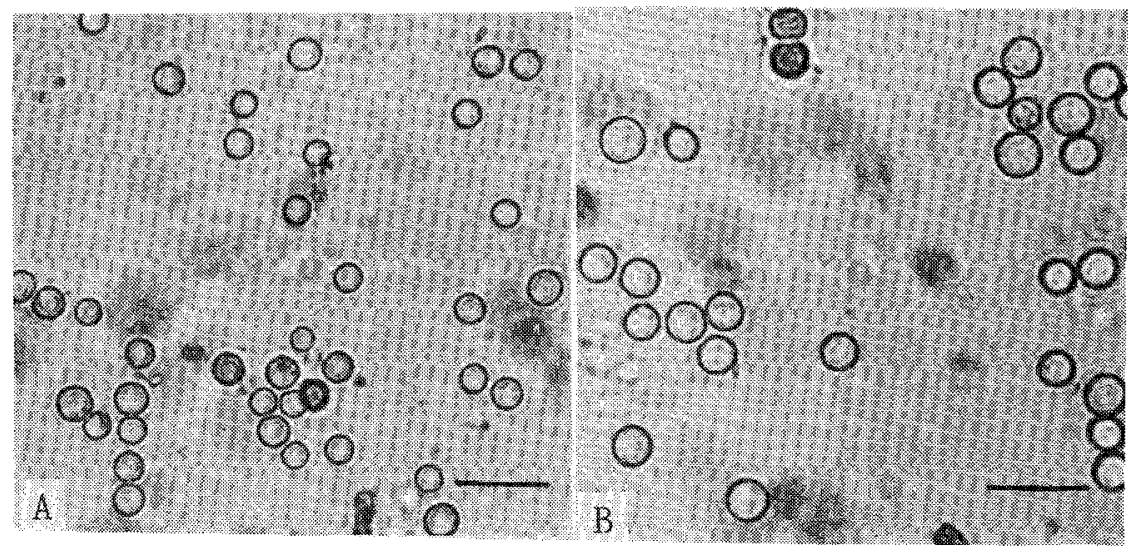

FiG. 3. Conidial Sizes of the Haploid and Diploid.

A, haploid from original parent strain $(\times 600)$; B, diploid $(\times 600)$. The bar marker represents $15 \mu \mathrm{m}$.

Table Vi. Properties of the Heterokaryon and Diploid

\begin{tabular}{lccc} 
Strain & $\begin{array}{c}\text { Citric acid produced } \\
\text { in koji }(\mathrm{g})\end{array}$ & $\begin{array}{c}\mathrm{pH} \text { of } \\
\text { koji extract }\end{array}$ & $\begin{array}{c}\text { Amylase activity }^{b} \\
\text { (units/ml) }\end{array}$ \\
\hline Asp. awamori var. & & & 9.25 \\
kawachi KGS & 0.753 & 2.85 & 0.74 \\
KGS-1 (met) & 0.018 & 4.30 & 0.59 \\
KGS-2 (arg) & 0.035 & 4.15 & 1.00 \\
KGS-1-2-H (heterokaryon) & 0.072 & 3.50 & 9.25 \\
KGS-1-2-D (diploid) & 0.806 & 2.80 & \\
\hline
\end{tabular}

a The koji extract was prepared by extracting a solid culture with 10 volumes (for a fresh culture) of $0.1 \mathrm{M}$ acetate buffer, $\mathrm{pH} 5.0$, at room temperature for $1 \mathrm{hr}$.

$b$ Amylase activity is expressed as saccharifying activity. 
heterokaryons. When the heterokaryotic strains were incubated on MM agar containing $0.1 \% d$-camphor, black sectors developed, and then germ tubes from a part of the conidia in the sectors were observed.

In this study, more than 50 strains were isolated, 20 of which were subjected to conidial analysis. One of the conidia that germinated on MM agar, strain KGS-1-2-D, was also able to grow on MM agar, and segregated spontaneously into same recombinants. Moreover, the conidium from strain KGS-1-2-D, showed a 2 fold DNA content and an about 1.4 fold conidial diameter compared with those of the original strain, KGS. On the basis of these facts, it seemed reasonable to assume that strain KGS-1-2-D was a heterozygous diploid. The diploid strain, KGS-1-2-D, was regarded as a useful strain exhibiting high strong citric acid and amylase productivities, corresponding to those of the original strain, KGS.

Furuya et $a l^{4)}$ have successfully obtained stable diploids from $A$. oryzae through protoplast fusion of a protease-improved mutant and its healthy parent. It is known that a diploid strain obtained through fusion of single nucleic protoplasts shows an about 1.3 fold conidial diameter compared to the haploid and a 2 fold DNA content per conidium. The DNA content per conidium or nucleus of $A$. awamori var. kawachi KGS was similar to those Aspergillus nidulans ${ }^{17)}$ and Aspergillus sojae. ${ }^{18)}$

From the results presented it would appear that protoplast fusion will be a useful tool as to the genetics and mechanisms of breeding of koji-mold.

\section{REFERENCES}

1) L. Ferenzy, F. Kevei and M. Szegedi, Experimentia, 31, 1028 (1975).

2) L. Ferenzy, M. Szegedi and F. Kevei, Experimentia, 33, 184 (1976).

3) J. Anne, H. Essen and P. De Somer, Nature, 262, 719 (1976).

4) T. Furuya, M. Ishige and K. Uchida, Nippon Nogeikagaku Kaishi, 57, 1 (1983).

5) B. Lasker and T. P. Borgia, Abstracts of the Meeting, National Meeting of the American Microbial Society, Hawaii, 1979, p. 129.

6) T. Ohnuki, Y. Etoh and T. Beppu, Agric. Biol. Chem., 46, 451 (1982).

7) N. Toyama, H. Ohara and K. Ogawa, Bull. Fac. Agric. Miyazaki Univ., 31, 91 (1984).

8) K. Ogawa, J. A. Brown and T. M. Wood, Enzyme Microb. Technol., 9, 229 (1987).

9) A. J. Brown, K. Ogawa and T. M. Wood, Enzyme Microb. Technol., 9, 527 (1986).

10) J. B. Sumner, J. Biol. Chem., 65, 393 (1925).

11) K. Ogawa, H. Toyama and N. Toyama, Bull. Fac. Agric., Miyazaki Univ., 26, 387 (1981).

12) J. Anne and J. F. Peberdy, J. Gen. Microbiol., 92, 413 (1976).

13) K. Burton, Biochem. J., 62, 315 (1956).

14) W. C. Schneider, I. Biol. Chem., 164, 747 (1946).

15) I. Garcia Acha, F. Lopez-Belmonte and J. R. Villanueva, J. Gen. Microbiol, 45, 515 (1966).

16) G. Pontecorvo, Adv. in Genetics, 5, 141 (1953).

17) G. C. Heagy and J. A. Roper, Nature, 170, 713 (1952).

18) S. Ushijima and T. Nakadai, Agric. Biol. Chem., 51, 1051 (1987). 